Original Article

\title{
HEALTH-RELATED QUALITY OF LIFE IN EARLY BREAST CANCER PATIENTS WITH HORMONE RESPONSIVE
}

\author{
FEF RUKMININGSIHa, TRI MURTI ANDAYANI ${ }^{b}$, FITA RAHMAWATIb, KARTIKA WIDAYATIc
}

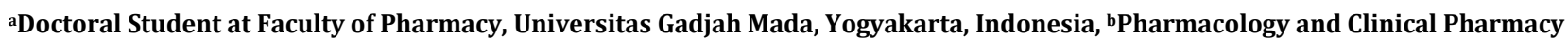
Department, Faculty of Pharmacy, Universitas Gadjah Mada, Yogyakarta, Indonesia, Internal Medicine Department, Faculty of Medicine, Universitas Gadjah Mada, Yogyakarta, Indonesia Email: fefrukminingsih@gmail.com

Received: 09 Sep 2018 Revised and Accepted: 27 Oct 2018

\section{ABSTRACT}

Objective: The management of early breast cancer (EBC) is performed with a series of treatments consisting of surgery and systemic therapy, along with long-term endocrine therapy for hormone responsive. The treatment generates a high illness effect that will affect the life quality of EBC patients. The objective of this study was to measure EBC patients' quality of life after undergoing the treatment.

Methods: A cross-sectional study was conducted by interviewing EBC patients using EQ-5D-5L instrument at private hospitals in Yogyakarta and Semarang, Indonesia. The EBC patients were women aged 18-60 y who had undergone surgery in 2010-2013 and received endocrine therapy.

Results: Of the 71 patients identified, 45 patients were in disease-free survival (DFS) state, 8 patients were in locoregional recurrence (LR), and 18 patients were in metastasis (M) state. Mobility and self-care problems occurred in patients who had metastasis (4.23\%). The problem of usual activities occured in patients who had recurrence $(22.54 \%)$. Most of the patients (84.51\%) had pain problem, and all patients had an anxiety problem. The mean utility score (SD) in DFS patients was 0.841 (0.052), in LR patients was $0.758(0.092)$, and in patients who had metastasis was $0.653(0.104)$. The mean scores of EQ-5D VAS (SD) for EBC patients in DFS, LR and M health state were 86.56 (6.29), 81.88 (5.30), and 69.17 (5.75), respectively.

Conclusion: The health states of EBC significantly affect HRQOL of patients. Efforts should be made to improve the quality of life of EBC patients especially in terms of pain and anxiety reduction.

Keywords: Early breast cancer, EQ-5D-5L, HRQOL, Utility

(c) 2018 The Authors. Published by Innovare Academic Sciences Pvt Ltd. This is an open access article under the CC BY license (http://creativecommons.org/licenses/by/4.0/) DOI: http://dx.doi.org/10.22159/ijpps.2018v10i12.29648

\section{INTRODUCTION}

Cancer is the second leading cause of death in the world. The incidence of cancer in 2030 is estimated to affect 26 million people and 17 million of them presumably die [1]. Breast cancer is a type of cancer mostly suffered and feared by women [2]. EBC is a surgical breast cancer since the cancer cells have not metastasized yet. EBC can occur in patients who have not been in menopause state (premenopausal) and who have been in menopause state (postmenopausal). Hormone-responsive testing is required to determine the type of therapy because adjuvant therapy is determined by hormone involvement (Estrogen Receptor) [3]. Based on Hospital Information System data throughout Indonesia in 2010, cases of hospitalization of breast cancer were 12.014 [1].

Breast cancer management is performed with a series of treatments including surgery, chemotherapy, radiation, endocrine therapy, and targetted therapy. This series of treatments is intended to destroy cancer cells or limit the progression of cancer and eliminate the symptoms [4]. A long duration of breast cancer treatment can have a high pain effect, bringing in even weaker conditions and depression. Such circumstances will affect the quality of life in patients with breast cancer $[5,6]$.

Iinstruments that can be used to measure health-related quality of life (HRQOL) in cancer patients are a specific instrument and generic instrument [7]. Generic preferential-based measurements from HRQOL are commonly used in the economic evaluation of health interventions [8]. EQ-5D is a generic instrument widely used to evaluate HRQOL [9]. $\mathrm{EQ}-5 \mathrm{D}$ consists of two parts: the EQ-5D descriptive system and the EQ$5 \mathrm{D}$ visual analogue (EQ-5D VAS). EQ-5D-5L is the latest version of EQ5D questionnaire. EQ-5D descriptive system can be reported as either a health profile or a weighted index. The weighted index is obtained by converting every health state of EQ-5D into a single summary index format called the EQ-5D index or utility. EQ-5D VAS records self-health values on a vertical and visual analogue. The scale ranges from 0 , as the worst health state, up to 100 , as the best health state. This information can be used as a quantitative measure of health outcomes assessed by individual respondents $[10,11]$.

Utility score is valuable in economic evaluation study and is required to calculate quality-adjusted life year (QALY), and subsequently to result in the cost-utility analysis (CUA) [12]. Utility generally ranges from 0 (death) to 1 (perfect health). This study aimed to measure the quality of life of EBC patients after undergoing the treatment.

\section{MATERIALS AND METHODS}

Subjects

This study was a cross-sectional study, conducted by interviewing EBC patients using EQ-5D-5L questionnaire at private hospitals in Yogyakarta and Semarang, Indonesia in the period of January to June 2017. Seventy-one EBC female patients with hormone-responsive, who have undergone surgery in 2010-2013 and received systemic therapy such as chemotherapy and endocrine therapy, were asked to participate in this study. Informed consents were provided to the patients before the interview.

\section{Data collection and analysis}

The patients were interviewed, and their medical records were reviewed to gain information regarding their clinical characteristics. The patients' characteristics were gathered in terms of age, medical intervention and their health state.

HRQOL was measured using the EQ-5D-5L instrument in the Indonesian language version. The EQ-5D-5L in official Indonesia language is provided by the Europol Group [13]. Utility (EQ-5D index score) values were calculated using the Indonesian value set [14] Descriptive analysis was used to present the HRQOL in terms of patients' health state, VAS and utility scores. 


\section{RESULTS AND DISCUSSION}

The mean age of the patients was $45.7 \mathrm{y}$ old $(\mathrm{SD}=6.03)$. All patients had been through medical intervention as well as surgery, chemotherapy and endocrine therapy.
Most patients did not receive radiation therapy (77.46\%). Regarding the health states, the proportions of patients in the state of diseasefree survival (DFS), locoregional recurrence (LR) and metastasis (M) were $63.38 \%, 11.27 \%$, and $25.35 \%$, respectively (table 1 ).

Table 1: Patient characteristics

\begin{tabular}{|c|c|c|c|c|}
\hline Characteristics & & & $\mathbf{n}$ & $\%$ \\
\hline Age (year) & mean \pm SD & $45.7 \pm 6.03$ & & \\
\hline \multirow[t]{8}{*}{ Medical intervention } & Surgery & Yes & 71 & 100 \\
\hline & & No & 0 & \\
\hline & Chemotherapy & Yes & 71 & 100 \\
\hline & & No & 0 & \\
\hline & Radiation therapy & Yes & 16 & 22.54 \\
\hline & & No & 55 & 77.46 \\
\hline & Endocrine therapy & Yes & 71 & 100 \\
\hline & & No & 0 & \\
\hline \multirow[t]{3}{*}{ Health states } & Disease-Free Survival & & 45 & 63.38 \\
\hline & Locoregional Recurrence & & 8 & 11.27 \\
\hline & Metastasis & & 18 & 25.35 \\
\hline
\end{tabular}

Descriptive statistics of EQ-5D regarding health state showed that mobility and self-care problems occurred in the patients who had metastasis $(4.23 \%)$. Problems of usual activities occured in the patients who had a recurrence (22.54\%). Most of the patients (84.51\%) had pain problem, and all of the patients had an anxiety problem (table 2).

Table 2: Patients' responses to EQ-5D-5L descriptive system

\begin{tabular}{|c|c|c|c|c|c|c|}
\hline \multirow[t]{2}{*}{ Dimension } & & \multicolumn{3}{|c|}{ Health states } & \multirow[t]{2}{*}{$\mathbf{n}$} & \multirow[t]{2}{*}{$(\%)$} \\
\hline & & DFS & LR & $\mathbf{M}$ & & \\
\hline \multirow{2}{*}{ Mobility } & No problem & 45 & 8 & 15 & 68 & 95.77 \\
\hline & Have problem & 0 & 0 & 3 & 3 & 4.23 \\
\hline \multirow[t]{2}{*}{ Self-care } & No problem & 45 & 8 & 15 & 68 & 95.77 \\
\hline & Have problem & 0 & 0 & 3 & 3 & 4.23 \\
\hline \multirow[t]{2}{*}{ Usual activity } & No problem & 45 & 4 & 6 & 55 & 77.46 \\
\hline & Have problem & 0 & 4 & 12 & 16 & 22.54 \\
\hline \multirow[t]{2}{*}{ Pain/discomfort } & No problem & 11 & 0 & 0 & 11 & 15.49 \\
\hline & Have problem & 34 & 8 & 18 & 60 & 84.51 \\
\hline \multirow{2}{*}{ Anxiety/depression } & No problem & 0 & 0 & 0 & 0 & 0 \\
\hline & Have problem & 45 & 8 & 18 & 71 & 100 \\
\hline
\end{tabular}

DFS=disease free survival, LR=locoregional recurrence, $M=$ metastasis

The EQ-5D health states of EBC patients showed that most of the patients had pain/discomfort problem and all of the patients had anxiety/depression. This study's finding was similar to the results of previous studies in Penang, Malaysia [15] and Makasar, Indonesia [5]

The utility scores tended to decrease from health states DFS, LR to $M$. The mean utility score (SD) in the DFS patients was 0.841
(0.052), in the LR patients was 0.758 (0.092), and in the patients who had metastasis was $0.653(0.104)$. The VAS scores also tended to decrease from health states DFS, LR to M.

The mean scores of EQ-5D VAS (SD) were 86.56 (6.29), 81.88 (5.30), and 69.17 (5.75) for EBC patients in health state DFS, LR and $\mathrm{M}$, respectively (table 3 ).

Table 3: Descriptive of EQ-5D VAS score and EQ-5D index score classified by health states

\begin{tabular}{|c|c|c|c|c|c|c|c|c|c|c|}
\hline \multirow[t]{3}{*}{ Health State } & \multicolumn{5}{|c|}{ EQ-5D VAS scores } & \multicolumn{5}{|c|}{ EQ-5D index scores } \\
\hline & \multirow[t]{2}{*}{ Mean } & \multirow[t]{2}{*}{ SD } & \multicolumn{2}{|c|}{$95 \%$ CI of mean } & \multirow[t]{2}{*}{ SE } & \multirow[t]{2}{*}{ Mean } & \multirow[t]{2}{*}{ SD } & \multicolumn{2}{|c|}{$95 \%$ CI of mean } & \multirow[t]{2}{*}{ SE } \\
\hline & & & Lower & Upper & & & & Lower & Upper & \\
\hline DFS & 86.56 & 6.29 & 84.67 & 88.45 & 0.94 & 0.841 & 0.052 & 0.825 & 0.856 & 0.008 \\
\hline LR & 81.88 & 5.30 & 77.44 & 86.31 & 1.88 & 0.758 & 0.092 & 0.681 & 0.835 & 0.032 \\
\hline M & 69.17 & 5.75 & 66.31 & 72.03 & 1.36 & 0.653 & 0.104 & 0.602 & 0.705 & 0.024 \\
\hline
\end{tabular}

*EQ-5D=Euro Quality of Life five dimension; VAS=visual analogue scale; $95 \% \mathrm{CI}=95 \%$ confidence interval; SD=standard deviation; SE=standard error

The cancer itself, cancer treatment and non-cancer health condition were the contributors to cancer pain [16]. If not managed, cancer pain could link to emotional distress that leads to depression and anxiety $[17,18]$, which eventually worsen the patient's quality of life. The history of having anxiety or trauma, avoiding coping style, social isolation, and life roles/caregiver; cancer-related fears; disease and treatment factors; as well as comorbidity such as pain, insomnia, fatigue, dyspnea, and depression were contributing factors of anxiety in cancer patients [19]

EBC significantly affects HRQOL of patients. Therefore, efforts should be made to improve HRQOL of EBC patients especially in terms of pain/discomfort and anxiety/depression reduction. The recommendations to prevent and reduce anxiety in cancer patients are cognitive and behavioral interventions, relaxation training, 
supportive counseling, and education; as well as pharmacologic interventions using medications such as anxiolytics and antidepressants [19]. This study also found that the EQ-5D VAS and utility scores tended to decrease from health states DFS, LR to M.

\section{CONCLUSION}

This study has confirmed that health states of EBC significantly affect HRQOL of patients. Efforts should be made to improve the quality of life of EBC patients especially in terms of pain/discomfort and anxiety/depression reduction.

\section{LIMITATION}

This study was conducted with a limited number of patients at two private hospitals in Java, and the findings may not be generalizable for another hospital or another country. However, the findings provide important information for future research since nearly all the health-related quality of life of EBC patients with hormoneresponsive lack evidence.

\section{ACKNOWLEDGMENT}

This study was supported by a grant from Directorate General of Higher Education, Indonesian Ministry of Research, Technology and Higher Education.

\section{AUTHORS CONTRIBUTIONS}

The first author contributed to all of the writing processes. The second, third and fourth authors contribute to the concept, design, definition of intellectual content, manuscript preparation, editing, review, and guarantor of the manuscript.

\section{CONFLICTS OF INTERESTS}

All authors have none to declare

\section{REFERENCES}

1. Kementerian Kesehatan Republik Indonesia. Stop kanker. Jakarta: Pusat data dan informasi Kementerian Kesehatan Republik Indonesia; 2015.

2. Mulyani S. Menopause: end of the menstrual cycle. In: Women in the Middle Ages. Yogyakarta: Nuha Medika; 2013.

3. Senkus E, Kyriakides S, Ohno S, Penault-Llorca F, Poortmans P, Rutgers E, et al. Primary breast cancer: ESMO clinical practice guidelines for diagnosis, treatment and follow up. Annal Oncol 2015;26:8-30.

4. Suyatno. Breast Cancer. Bedah onkologi diagnostik dan terapi. Jakarta: Sagung Seto; 2010.

5. Palu MB, Nurdin AA. Lost potency based on the health-related quality of life on breast cancer in Makasar South Sulawesi. Medula 2014;2:97-107.
6. Sanigaram V, Lingampally S, Boyana A, Vurumadla S. A prospective study on clinical evaluation, treatment pattern and adverse effects of anticancer drugs in various gynaecological cancer patients. Asian J Pharm Clin Res 2015;8:125-31.

7. Teckle P, Peacock S, McTaggart Cowan H, Hoek KVD, Chia S, Melosky B, et al. The ability of cancer-specific and generic preference-based instruments to discriminate across clinical and self-reported measures of cancer severities. Health Quality Life Outcomes 2011;9:106.

8. Longworth L, Yang Y, Young T, Mulhern B, Hernandez AM, Mukuria C, et al. Use of generic and condition-specific measures of health-related quality of life in NICE decision-making: a systematic review, statistical modeling, and survey. Health Technol Assess 2014;18:1-224.

9. Devlin NJ, Krabbe PF. The development of new research methods for the valuation of EQ-5D-5L. Eur J Health Econ 2013;14 Suppl 1:S1-3.

10. Oemar M, Janssen B. User guide: basic information on how to use EQ-5D-5L instrument. EuroQol Group; 2013.

11. Oemar $M$, Oppe $M$. User guide: basic information on how to use EQ-5D-3L instrument. Eur Qol Group; 2013.

12. Drummond F, Torrance GW. Methods for the economic evaluation of health care programmes. New York: Oxford University Press; 2005.

13. Euro Qol Group. EQ-5D-5L. Available from: http://www. euroqol.org/eq-5d-products/eq-5d-5l.html. [Last accessed on 12 Jun 2016].

14. Purba FD, Hunfeld JAM, Iskandarsyah A, Fitriana TS, Sadarjoen SS, Passchier J, et al. The indonesian EQ-5D-5L value set. Pharmacol Economics 2017;35:1153-65.

15. Matalqah LM, Radaideh KM, Yusoff ZM, Awaisu A. Healthrelated quality of life using EQ-5D among breast cancer survivors in comparison with age-matched peers from the general population in the state of Penang, Malaysia. J Public Health 2011;19:475-80.

16. Marcus DA. Epidemiology of cancer pain. Curr Pain Headache Rep 2011;15:231-4.

17. Galloway SK, Baker M, Giglio P, Chin S, Madan A, Malcolm R, et al. Depression and anxiety symptoms relate to distinct components of pain experience among patients with breast cancer. Pain Res Treat 2012;851276. Doi: 10.1155/2012/ 851276.

18. Balaji O, Bairy KL, Veena N. Management of depression in terminally ill patients-a critical review. Asian J Pharm Clin Res 2017;10:31-6.

19. Traeger L, Greer JA, Fernandez Robles C, Temel JS, Pirl WF. Evidence-based treatment of anxiety in patients with cancer. J Clin Oncol 2012;30:1197-205. 